\title{
Recombinant human erythropoietin administration in cardiac surgery
}

Levent Yazicioğlu, MD

Sadık Eryilmaz, MD

Mustafa Şirlak, MD

Mustafa Bahadır inan, MD

Atilla Aral, MD

Refik Taşöz, MD

Neyyir Tuncay Eren, MD

Bülent Kaya, MD

Hakkı Akalin, MD
From the Department of Cardiovascular Surgery, Ankara University Faculty of Medicine Hospital, Ankara, Turkey.

Received for publication Oct 17, 2000; revisions requested Jan 2, 2001; revisions received Feb 5, 2001; accepted for publication Feb 20, 2001.

Address for reprints: Levent Yazicioğlu, Bilkent 2 Park Sitesi G-4 Blok No: 22/32, 06530 Ankara, Turkey (E-mail: hyazici@ domi.com.tr).

J Thorac Cardiovasc Surg 2001;122:741-5

Copyright (c) 2001 by The American Association for Thoracic Surgery

$0022-5223 / 2001 \$ 35.00+0 \quad \mathbf{1 2 / 1 / 1 1 5 4 2 6}$

doi:10.1067/mtc.2001.115426
Objective: Postoperative anemia and multiple blood transfusions are still important problems in cardiac surgery. During the past few years, there have been some reports indicating that multiple recombinant human erythropoietin infusions starting at least 2 weeks before the operation induced erythropoiesis. We aimed to reduce the risk of adverse reactions of high doses of recombinant human erythropoietin and reduce the period of hospitalization by using it only once, 4 days before the operation.

Methods: Twenty-five patients received recombinant human erythropoietin 4 days before the operation, and 28 patients comprised the control group. All the hematologic parameters of the patients are measured on the day of admission, the day before the operation (fourth day), the first day after the operation, and 1 week later.

Results: In the recombinant human erythropoietin group the mean hemoglobin concentration increased on the morning of the operation $(14.5 \pm 0.52 \mathrm{~g} / \mathrm{dL}$ in the recombinant human erythropoietin group and $12.4 \pm 0.65$ in the control group, $P<$ $.05)$. To maintain hemoglobin levels at greater than $8.5 \mathrm{~g} / \mathrm{dL}, 330 \pm 33 \mathrm{~mL}$ of homologous transfusion was required in the recombinant human erythropoietin group, whereas $680 \pm 75 \mathrm{~mL}$ was required in the control group $(P<.01)$.

Conclusion: Recombinant human erythropoietin induces erythropoiesis rapidly, even when it is used with a low single dose just 4 days before the operation. No adverse reactions were seen with this kind of recombinant human erythropoietin treatment.

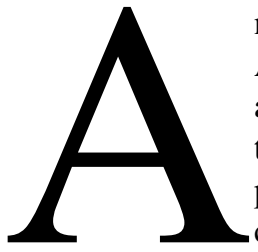

nemia is one of the main problems seen after cardiac surgery. Activation of the contact coagulation factors during extracorporeal circulation causes activation of the complex fibrinolytic system. ${ }^{1-3}$ Studies have shown that there are major reductions in the plasma levels of almost all factors, but most of these changes are caused by hemodilution. ${ }^{4,5}$ Moreover, cardiopulmonary bypass (CPB) shortens the erythrocyte life by increasing its fragility. ${ }^{6-8}$ Because of the reasons mentioned above and despite the meticulous surgical hemostasis, blood loss can be so great as to cause anemia. For the treatment of this anemia, whole blood and blood products are used, which also causes a lot of problems, such as transfusion reactions, volume overload, and infections. ${ }^{9-11}$ 
There are many reports on blood salvage methods, diminishing blood loss, materials used instead of whole blood, and drugs that induce erythropoiesis. Autologous donation is the most preferred method to replace blood, fresh platelets, and coagulation factors; however, anemia is a common problem in cardiac surgery, even if autologous transfusion was made.

In 1977, Miyake and colleagues ${ }^{12}$ isolated erythropoietin (EPO) hormone, which induces erythropoiesis, and in 1985, Jacob and colleagues ${ }^{13}$ produced recombinant human EPO (r-Hu EPO) for the first time by using recombinant DNA technology, and this has been a great development for the treatment of the anemia caused by diminished erythropoiesis. At present, r-Hu EPO has become the main agent in treating the anemia caused by reduced erythropoiesis, which is seen in chronic renal insufficiency and some hematologic diseases. ${ }^{14,15}$

In this study we aimed to investigate the effect of lowand single-dose (100 IU/kg) r-Hu EPO on erythropoiesis by using it 4 days before the operation.

\section{Methods}

This single-blind study included 53 patients who were randomly chosen from those waiting for elective coronary artery bypass grafting surgery between October 1999 and February 2000. Only the nurse who had done the injections knew which patients belonged to which group. All the patients were informed about the study, informed consent was obtained, and institutional review board approval was taken. Twenty-eight of the subjects formed the control group. The remaining 25 patients received $100 \mathrm{IU} / \mathrm{kg} \mathrm{r}-\mathrm{Hu}$ EPO intravenously 4 days before the operation (r-Hu EPO group). Hemotologic system analysis of the patients was normal. Patients in this study did not receive supplementary iron. None of these patients had any disease or addiction (eg, drug abuse, alcohol abuse, and corticosteroid treatment) that might possibly affect bone marrow response. The mean time between the admission and cardiac catherization was $11.3 \pm 9$ days (up to 64 days). None of the patients were operated urgently. The characteristics of both groups are shown in Table 1 . There is no statistically significant difference in the preoperative characteristics between the 2 groups.

The complete blood cell counts, routine serum chemical parameters, serum iron values, iron-binding capacity values, and serum EPO levels were measured on admission, on the day before the operation (4 days after admission), on the first postoperative day, and 1 week after the operation. Complete blood cell counts were performed with the Coulter STK 5 (Coulter Corporation, Hialeah, Fla), and EPO levels were measured with an enzyme-linked immunosorbent assay (Quantikine IVD catalog number DEP00). The reticulocyte levels were measured by using the manual method. All patients donated $400 \mathrm{~mL}$ of their own blood on the morning of the operation. This blood was conserved and given back to the patients after protamine administration. All patients underwent successful coronary bypass surgery without major complications. All operations were carried out with CPB with the SciMed membrane oxygenator (SciMed/Boston Scientific Corporation, Osseo, Minn), cold potassium cardioplegic solution, and moderate hypothermia. During CPB, the hematocrit level was maintained over $20 \%$, and all the blood in the circuit was reinfused. One large-bored, silicone-coated thoracic drain was placed in mediastinum, and thoracic cavities were drained separately if required. Postoperative drainage was collected to an underwater drainage system, and the shed blood was not reinfused. Patients' lungs were ventilated with volume-controlled ventilators for at least 4 hours (mean, 6 hours). A positive end-expiratory pressure of 5 to $10 \mathrm{~mm} \mathrm{Hg}$ was used unless hemodynamic instability was present. In the postoperative period, hematocrit levels of the patients were kept above $28 \%$ ( $8.5 \mathrm{~g} / \mathrm{dL}$ hemoglobin) by administration of blood.

All data were expressed as means \pm standard deviation. The statistical evaluation of the results has been made according to the Student $t$ test and test for 2 proportions from independent groups.

\section{Results}

All patients underwent successful coronary bypass surgery without major complications. None of the patients underwent reoperation. They have completed their postoperative course, and they were discharged on the eighth to eleventh postoperative days.

On admission to the hospital, there was no significant difference in hemoglobin values between the 2 groups (control group, $12.5 \pm 0.51 \mathrm{~g} / \mathrm{dL}$; $\mathrm{r}-\mathrm{Hu}$ EPO group, $12.1 \pm 0.38$ $\mathrm{g} / \mathrm{dL} ; P>.05)$. After r-Hu EPO administration, hemoglobin values were elevated significantly $(14.5 \pm 0.52 \mathrm{~g} / \mathrm{dL})$ in the $\mathrm{r}-\mathrm{Hu}$ EPO group, and this finding was significantly different from those in the control group $(P<.05)$. Therefore, the preoperative hemoglobin values were higher in the r-Hu EPO group than in the control group. The hemoglobin values measured 24 hours after the operation were not significantly different between the 2 groups (control group, $10.3 \pm 0.60$ $\mathrm{g} / \mathrm{dL} ; \mathrm{r}-\mathrm{Hu}$ EPO group, $11.2 \pm 0.72 \mathrm{~g} / \mathrm{dL} ; P>.05)$. In our intensive care unit, hemoglobin values of the patients were measured every 3 hours in the first 24 hours after the operation, and the patients with lower hemoglobin values received homologous blood transfusion. There is no significant difference between the hemoglobin values of the 2 groups at the end of the first week (control group, $11.5 \pm$ $0.58 \mathrm{~g} / \mathrm{dL} ; \mathrm{r}-\mathrm{Hu}$ EPO group, $12.1 \pm 0.62 \mathrm{~g} / \mathrm{dL} ; P>.05)$.

In the $\mathrm{r}-\mathrm{Hu} \mathrm{EPO}$ group the patients received $330 \pm 43 \mathrm{~mL}$ of homologous blood transfusion from the time of operation until discharge from the hospital. The control group received $680 \pm 75 \mathrm{~mL}$ of homologous blood during the same period. The difference between the 2 groups was found to be significant $(P<.01)$.

There was no significant difference in the reticulocyte values between both groups when they were admitted to the hospital (control group, $55 \pm 9.80 / \mathrm{mm}^{3}$; r-Hu EPO group, $\left.51 \pm 7.01 / \mathrm{mm}^{3} ; P>.05\right)$. The patients who received $\mathrm{r}-\mathrm{Hu}$ EPO had significantly higher reticulocyte values after the rHU EPO administration than those in the control group (control group, $53 \pm 8.20 / \mathrm{mm}^{3}$; r-Hu EPO group, $135 \pm$ 
$\left.15.07 / \mathrm{mm}^{3} ; P<.01\right)$. Even though the reticulocyte values increased slightly in the control group 24 hours after the operation, the difference in these values between the 2 groups was found to be significant (control group, $68 \pm$ $8.06 / \mathrm{mm}^{3}$; r-Hu EPO group, $\left.126 \pm 9.35 / \mathrm{mm}^{3} ; P<.01\right)$. At the end of the first week, the reticulocyte values decreased in the r-Hu EPO group, but they were still higher than admission values, whereas they had increased slightly in the control group. Therefore, no significant difference was observed between the 2 groups at the end of the first week (control group, $88 \pm 9.99 / \mathrm{mm}^{3} ; \mathrm{r}-\mathrm{Hu}$ EPO group, $75 \pm$ $\left.10.35 / \mathrm{mm}^{3} ; P>.05\right)$, but these reticulocyte levels of both groups were significantly higher than the hospitalization levels $(P<.05)$.

There was no statistically significant difference in the serum EPO values between the 2 groups $(P>.05)$. However, the postoperative serum EPO values of the control group were slightly higher than the preoperative values of the same group, and this elevation was not statistically significant $(P>.05)$. The brevity of the elimination half-life of $r-$ Hu EPO (4 hours) did not cause any change in the serum EPO levels of the patients.

All preoperative and postoperative serum iron and iron-binding capacity values were not significantly different between the 2 groups $(P>.05)$. All data are shown in Table 2.

During the first 24-hour period postoperatively, $470 \pm 45$ $\mathrm{mL}$ of drainage was observed in the control group, whereas $430 \pm 40 \mathrm{~mL}$ of drainage was detected in the r-Hu EPO group. There was no significant difference in the drainage fluid values between the 2 groups $(P>.05)$.

\section{Discussion}

Anemia is still one of the main problems seen after cardiac surgery. Today, it is still controversial under which hemoglobin value we should transfuse whole blood, blood products, or both. There are several authors who propose transfusion under the hemoglobin values of $6 \mathrm{~g} / \mathrm{dL}$ (this limit is much lower in children), whereas others stated that transfusion should be made to the patients with hemoglobin values of 8.5 to $9.0 \mathrm{~g} / \mathrm{dL} .{ }^{16-19}$ Low hemoglobin values have great effect on postoperative morbidity. For this reason, we do not permit hemoglobin values under $8.5 \mathrm{~g} / \mathrm{dL}$ in our patients.

Blood should be used in the prime solution before undergoing CPB for the patients who had anemia preoperatively, so that extreme decreases in the hemoglobin values during the $\mathrm{CPB}$ are prevented.

It was observed that the patients who received r-Hu EPO had induced erythropoiesis in a short period of time and had a marked increase in their hemoglobin values. The hemoglobin value of the r-Hu EPO group was $12.1 \pm 0.38 \mathrm{~g} / \mathrm{dL}$ as they were hospitalized and 4 days after r-Hu EPO administration, and on the day of operation, the values increased to
TABLE 1. Characteristics of patients

\begin{tabular}{lcc}
\hline & Control group & r-Hu EPO group \\
\hline No. of patients & 28 & 25 \\
Age (y) & & \\
$\quad$ Mean & $56.2 \pm 4.7$ & $59.8 \pm 5.4$ \\
Minimum & 38 & 36 \\
$\quad$ Maximum & 77 & 80 \\
Sex & & \\
$\quad$ Male & 17 & 16 \\
$\quad$ Female & 11 & 9 \\
Weight (kg) & $68.7 \pm 9.2$ & $70.3 \pm 8.3$ \\
Mean hospitalization (d) & $9.1 \pm 0.6$ & $9.7 \pm 0.8$ \\
Crossclamp time (min) & $51.2 \pm 6.2$ & $47.7 \pm 5.9$ \\
Total operative time (min) & $192.6 \pm 11.4$ & $211.6 \pm 14.6$ \\
Revascularized coronary arteries (n) & $2.7 \pm 0.4$ & $3.2 \pm 0.5$ \\
\hline
\end{tabular}

$14.5 \pm 0.52 \mathrm{~g} / \mathrm{dL}$. The difference between these values appeared to be statistically significant $(P<.01)$. The hemoglobin value of the control group was $12.4 \pm 0.65 \mathrm{~g} / \mathrm{dL}$ on the day of the operation. The difference between the 2 groups' hemoglobin values was statistically significant $(P<$ $.05)$. Therefore, the patients in the r-Hu EPO group had undergone the operations with higher hemoglobin values than those in the control group. However, another study still going on in our center showed that r-HU EPO treatment in normal patients who had hemoglobin levels of more than $13.5 \mathrm{~g} / \mathrm{dL}$ had no significant changes in 4 days.

During the period between the operation and the discharge from the hospital, the patients in the r-Hu EPO group received $330 \pm 33 \mathrm{~mL}$ of homologous blood transfusion. The patients in the control group were transfused with 680 $\pm 75 \mathrm{~mL}$ of homologous blood during the same period. The difference between the 2 groups was statistically significant $(P<.01)$. Therefore, it was observed that the requirement of blood products for the EPO group is less than that for the subjects in the control group.

Studies about r-Hu-EPO administration before cardiac surgery have been reported in the literature. ${ }^{20-25}$ Moreover, Watanabe and colleagues ${ }^{26}$ reported the administration of the r-Hu EPO in the week after the operation in addition to preoperative use. Also, there are reports about administration of r-Hu EPO in multiple doses. Kiyama and associates $^{27}$ reported 3 weeks' (once weekly) use of r-Hu EPO in anemic patients before the cardiac operation, but this has the disadvantage of overstay in the hospital. In all these studies, hemoglobin values showed a marked increase, and the requirement for blood and blood products markedly decreased. Treatment with r-Hu EPO can result in hypertension, deep venous thrombosis, hypercalcemia, flulike syndrome, and headache-like side effects. ${ }^{28,29}$ These side effects are usually seen in patients who undergo chronic r$\mathrm{Hu}$ EPO treatment. In our study we did not observe any 
TABLE 2. Hematologic values of both groups before and after r-Hu EPO administration

\begin{tabular}{|c|c|c|c|c|c|c|}
\hline & \multicolumn{3}{|c|}{ Admission } & \multicolumn{3}{|c|}{ Operative morning } \\
\hline & Control & r-Hu EPO & $P$ value & Control & r-Hu EPO & $P$ value \\
\hline Hemoglobin levels ( $g / d L)$ & $12.5 \pm 0.51$ & $12.1 \pm 0.38$ & $>.05$ & $12.4 \pm 0.65$ & $14.5 \pm 0.52$ & $<.05$ \\
\hline Reticulocyte count $\left(/ \mathrm{mm}^{3}\right)$ & $55 \pm 9.80$ & $51 \pm 7.01$ & $>.05$ & $53 \pm 8.20$ & $135 \pm 15.07$ & $<.01$ \\
\hline Erythropoietin levels (mU/mL) & $10.4 \pm 1.21$ & $9.3 \pm 1.50$ & $>.05$ & $9.6 \pm 1.72$ & $12.1 \pm 3.30$ & $>.05$ \\
\hline Serum iron levels ( $\mu \mathrm{g} / \mathrm{dL})$ & $95 \pm 11.44$ & $101 \pm 15.8$ & $>.05$ & $120 \pm 10.71$ & $106 \pm 12.46$ & $>.05$ \\
\hline Serum iron-binding capacity $(\mu \mathrm{g} / \mathrm{dL})$ & $336 \pm 41.4$ & $308 \pm 32.6$ & $>.05$ & $301 \pm 27.6$ & $320 \pm 35.6$ & $>.05$ \\
\hline
\end{tabular}

TABLE 2. Cont'd

\begin{tabular}{|c|c|c|c|c|c|c|}
\hline & \multicolumn{3}{|c|}{ Postoperative day 1} & \multicolumn{3}{|c|}{ Postoperative day 7} \\
\hline & Control & r-Hu EPO & $P$ value & Control & r-Hu EPO & $P$ value \\
\hline Hemoglobin levels (g/dL) & $10.3 \pm 0.6$ & $11.2 \pm 0.72$ & $>.05$ & $11.5 \pm 0.58$ & $12.1 \pm 0.62$ & $>.05$ \\
\hline Reticulocyte count $\left(/ \mathrm{mm}^{3}\right)$ & $68 \pm 8.06$ & $126 \pm 9.35$ & $<.01$ & $88.0 \pm 9.99$ & $75 \pm 10.35$ & $>.05$ \\
\hline Erythropoietin levels (mU/mL) & $4.7 \pm 1.66$ & $6.8 \pm 1.82$ & $>.05$ & $10.8 \pm 2.19$ & $8.9 \pm 2.56$ & $>.05$ \\
\hline Serum iron levels $(\mu \mathrm{g} / \mathrm{dL})$ & $104 \pm 7.18$ & $98 \pm 9.62$ & $>.05$ & $101 \pm 14.2$ & $110 \pm 13.16$ & $>.05$ \\
\hline Serum iron-binding capacity $(\mu \mathrm{g} / \mathrm{dL})$ & $316 \pm 39.0$ & $333 \pm 31.6$ & $>.05$ & $296 \pm 32.6$ & $317 \pm 29.8$ & $>.05$ \\
\hline
\end{tabular}

complications caused by administration of r-Hu EPO. We think that single low-dose $\mathrm{r}-\mathrm{Hu}$ EPO administration might play a role in avoiding complications.

Blood and blood product transfusions may result in many adverse effects, such as transfusion reactions, volume overloading, or infections. Also, unnecessary use of blood and blood products should be avoided because they are difficult to obtain, and it is also expensive to prepare them. Therefore, we believe that by receiving a $100 \mathrm{IU} / \mathrm{kg}$ single dose of r-Hu EPO less than 1 week (4 days) before the operation, patients will have higher hemoglobin values before the operation, and the requirement of blood and blood products in the postoperative period will markedly decrease.

Doing this study in a double-blind, randomized fashion would be more scientific, but high costs of hospitalizing a nonsurgical patient forced us to do this study in the way described here, and we think this is the main weakness of the study. Because of this, we believe that subsequent studies done with nonsurgical patients will provide more information about this inexpensive blood conservation technique.

\section{References}

1. Fong SW, Burns NE, Williams G, et al. Changes in coagulation and platelet function during prolonged extracorporeal circulation in sheep and man. Trans Am Soc Artif Internal Organs. 1974;20:239-43.

2. Mammen EF, Koets MH, Washington BC, et al. Hemostasis changes during cardiopulmonary bypass surgery. Semin Thromb Hemost. 1985;11:281-4.

3. Wolk LA, Wilson RF, Burdick M, et al. Changes in antithrombin, antiplasmin and plasminogen during and after cardiopulmonary bypass. Am Surg. 1985;51:309-13.

4. Journois D, Mauriat P, Pouard P, et al. Assessment of coagulation factor activation during cardiopulmonary bypass with a new monoclonal antibody. J Cardiothorac Vasc Anesth. 1994;8:157-61.
5. Brody JI, Pickering NJ, Fink GB. Concentrations of Factor VIII-related antigen and Factor XIII during open heart surgery. Transfusion. 1986;26:478-84.

6. Yamaguchi H, Allers M, Roberts D. The effect on the red cell deformability during cardiopulmonary bypass. Scand $J$ Thorac Cardiovasc Surg. 1984;18:119-21.

7. Wright G. Blood cell trauma. In: Taylor KM, editor. Cardiopulmonary bypass. London: 1986; p. 249-56.

8. Cohen E, Neustein SM, Silvay G. Profound anemia following cardiac surgery. J Cardiothorac Vasc Anesth. 1993;7:721-3.

9. Borton JC. Nonhemolytic, noninfectious transfusion reactions. Semin Hematol. 1981;18:95-9.

10. Ward JW, Holmberg SD, Allen JR, et al. Transfusion of human immunodeficiency virus (HIV) by blood transfusions screened as negative for HIV antibody. $N$ Engl J Med. 1988;318:473-8.

11. Alter HJ, Purcell RH, Shih JW, et al. Detection of antibody to hepatitis virus in prospectively followed transfusion recipients with acute and chronic non A, non B hepatitis. N Engl J Med. 1989;321:1494-500.

12. Miyake T, Kung CKH, Goldwasser E. Purification of human erythropoietin. J Biol Chem. 1977;252:5558-64.

13. Jacobs K, Shoemaker C, Rudersdorf R, et al. Isolation and characterisation of genomic and cDNA clones of human erythropoietin. Nature. 1985;313:806-10.

14. Zins B, Drueke T, Zingraff J, et al. Erythropoietin treatment in anemia patients on haemodialysis. Lancet. 1986;11:1329.

15. Eschbach JW, Egrie JC, Downing MR, et al. Correction of the anemia of end-stage renal disease with recombinant human erythropoietin. $N$ Engl J Med. 1987;316:73-8.

16. Blum LL. Indications for blood transfusions. J Indiana State Med Assoc. 1967;60:583-4.

17. Simon TL. Indications for blood transfusions. Clin Lab Med. 1992;12:655-67.

18. Zuccala G, Bernabei R, Carbonin P. Perioperative blood transfusion. JAMA. 1998;279:1610.

19. McFarland JG. Perioperative blood transfusion: indications and operations. Chest. 1999;115(Suppl 5):113S-21S.

20. Goodnough LT. Potential role of recombinant human erythropoietin in the peri-surgical settings. Int J Cell Cloning. 1990;8(Suppl 1):203-10.

21. Helm RE, Gold JP, Rosengart TK, Zelano JA, Isom DW, Krieger KH. Erythropoietin in cardiac surgery. J Card Surg. 1993;8:579-606.

22. Rosengart TK, Helm RE, Klemperer J, Krieger KH, Isom DW. 
Combined aprotinin and erythropoietin use for blood conservation: results with Jehovah's Witnesses. Ann Thorac Surg. 1994;58:1397403.

23. Hayashi J, Shinonaga M, Nakazawa S, Miyamura H, Eguchi S, Shinada S. Does recombinant human erythropoietin accelerate erythropoiesis for predonation before cardiac surgery? Jpn Circ J. 1993;57:475-9.

24. Konishi T, Ohbayashi T, Kaneko T, Ohki T, Saitou Y, Yamato Y. Preoperative use of erythropoietin for cardiovascular operations in anemia. Ann Thorac Surg. 1993;56:101-3.

25. D'Ambra MN, Gray RJ, Hillman R, et al. Effect of recombinant human erythropoietin on transfusion risk in coronary bypass patients. Ann Thorac Surg. 1997;64:1686-93.
26. Watanabe Y, Fuse K, Konishi T, et al. Autologous blood transfusion with recombinant human erythropoietin in heart operations. Ann Thorac Surg. 1991;51:767-72.

27. Kiyama H, Ohshima N, Imazeki T, Yamada T. Autologous blood donation with recombinant human erythropoietin in anemic patients. Ann Thorac Surg. 1999;68:1652-6.

28. Neumayer HH, Brockmoller J, Fritschka E, Roots I, Scigalla P, Wattenberg M. Pharmacokinetics of recombinant human erythropoietin after sc. administration and in long term i.v. treatment in patients on maintenance haemodialysis. Contrib Nephrol. 1989;76:131-42.

29. Flaharty KK. Pharmacokinetics and erythropoietic response to human recombinant erythropoietin in healthy men. Clin Pharmacol Ther. 1990;47:557-63.

\section{JTCVS On-Line Manuscript Submission and Review}

\section{Please visit http://www.editorialmanager.com/jtcvs/}

Effective September 15, 2001, authors and reviewers may submit manuscripts and reviews electronically via Editorial Manager, our new Web-based system with full electronic submission, review, and status update capabilities.

As we move from paper to electronic submissions, the Editorial Office will make proxy submissions of all manuscripts accompanied by a diskette containing the electronic files of the text, tables, and figures. Editors, authors, and reviewers will receive automatic e-mails when significant events occur.

We strongly encourage all authors and reviewers to use Editorial Manager. Although we will continue to accommodate the submission of paper manuscripts for some months, our goal is to be completely electronic within 9 to 12 months.

All individuals currently in our database for whom we have e-mail addresses will receive via e-mail a system-assigned username and password that can be used to log in to the system without prior registration. All those not receiving the e-mail must register the first time they use the system.

As with any broad systemic change, the conversion to the new system will take some time to complete. We ask your patience as we replace our in-office database with the new system. We also encourage you to take advantage of the speed and efficiency that the new system will provide for us all: editor, author, reviewer, and publisher. 